\title{
New Hope for Wound Healing after Bowel Resection
}

\author{
Ryung-Ah Lee \\ Division of Coloproctology, Department of Surgery, Ewha Womans University School of Medicine, Seoul, Korea
}

\section{See Article on Page 132-139}

The anastomotic leakage is a crucial complication after colorectal surgery and has a variable incidence, occurring in up to 1.8 to $12 \%$ of cases [1-3]. The importance of this potential complication is emphasized to colorectal surgeons, especially in the case of lower rectal surgery, because it is a major cause of surgical morbidity and mortality, early local recurrence for cancer surgery and the need for advertent additional surgery. Also, leakage increases both the hospital stay and the medical cost. The stem cell engineering technique is an emerging field of medicine and has been put on the stage because of the hidden potential of stem cells. Collawn et al. [4] recently reported the effectiveness of adipose-derived stromal cells in the skin wound healing process. Adipose tissue is a major reservoir of mesenchymal stem cells, which can be differentiated into endothelial progenitors, adipocytes, chondrocytes, etc.

This article showed very promising results for the use of adipose stem cells in the bowel wall healing process. Rat adipose tissue harvested from the suprascapular and inguinal areas was used. After 14 days of organ culture, the outgrown cells in the fibrin matrix were recovered by selective degradation of the fibrin matrix, plated on tissue culture dishes, and propagated using a conventional two-dimensional culture. In vitro and in vivo experiments revealed that the experimental group showed significantly favorable histopathologic features, including less inflammation and more microvascular density. However, this feature does not confirm stem cell effects because vascular endothelial growth factor was used to induce endo-

Correspondence to: Ryung-Ah Lee, M.D.

Division of Coloproctology, Department of Surgery, Ewha Womans University School of Medicine, 1071 Anyangcheon-ro, Yangcheon-gu, Seoul 158-710,

Korea

Tel: +82-2-2650-2659, Fax: +82-2-2644-7984

E-mail: ralee@ewha.ac.kr

(C) 2012 The Korean Society of Coloproctology

This is an open-access article distributed under the terms of the Creative Commons Attribution NonCommercial License (http://creativecommons.org/licenses/by-nc/3.0) which permits unrestricted noncommercial use, distribution, and reproduction in any medium, provided the original work is properly cited. thelial differentiation during the cell manipulation stage. If this new technique is to be applied to clinical fields, an easier and more conventional process without additional pharmacological treatment would be expected.

\section{REFERENCES}

1. Yoon SJ, Kin JS, Min BS, Kim NK, Baik SH, Lee KY, et al. Risk factors for anastomotic leakage after a low anterior resection for rectal cancer. J Korean Soc Coloproctol 2007:23:365-73.

2. Veyrie N, Ata T, Muscari F, Couchard AC, Msika S, Hay JM, et al. Anastomotic leakage after elective right versus left colectomy for cancer: prevalence and independent risk factors. J Am Coll Surg 2007;205:785-93.

3. Kwon S, Morris A, Billingham R, Frankhouse J, Horvath K, Johnson $\mathrm{M}$, et al. Routine leak testing in colorectal surgery in the Surgical Care and Outcomes Assessment Program. Arch Surg 2012; 147:345-51.

4. Collawn SS, Banerjee NS, de la Torre J, Vasconez L, Chow LT. Adipose-derived stromal cells accelerate wound healing in an organotypic raft culture model. Ann Plast Surg 2012;68:501-4. 